\title{
New dinapinone derivatives, potent inhibitors of triacylglycerol synthesis in mammalian cells, produced by Talaromyces pinophilus FKI-3864
}

\author{
Mio Kawaguchi ${ }^{1}$, Ryuji Uchida ${ }^{1}$, Satoshi Ohte ${ }^{1}$, Natsuki Miyachi ${ }^{1}$, Keisuke Kobayashi ${ }^{1}$, Noriko Sato ${ }^{1}$, \\ Kenichi Nonaka ${ }^{2}$, Rokuro Masuma ${ }^{2}$, Takashi Fukuda ${ }^{1}$, Tadashi Yasuhara ${ }^{1}$ and Hiroshi Tomoda ${ }^{1}$
}

Eight new dinapinones, AB1, AB2, AC1, AC2, AD1, AD2, AE1 and AE2, were isolated from the culture broth of Talaromyces pinophilus FKI-3864. The structures of these dinapinones were elucidated by various NMR experiments. All these dinapinones possessed the same biaryl dihydronaphthopyranone skeleton consisting of a heterodimer with one monapinone $A$ and one different monapinone. Dinapinones $A B 1$ and $A B 2$, consisting of monapinones $A$ and $B$, were atropisomers. Similarly, dinapinones $A C 1$ and $A C 2$, consisting of monapinones $A$ and $C$, dinapinones $A D 1$ and $A D 2$, consisting of monapinones $A$ and $D$, and dinapinones $A E 1$ and $A E 2$, consisting of monapinones $A$ and $E$, were atropisomers. Dinapinone $A B 2$ showed potent inhibition of triacylglycerol (TG) synthesis in intact mammalian cells with an $\mathrm{IC}_{50}$ value of $1.17 \mu \mathrm{M}$, whereas the other dinapinones showed weak inhibition of TG synthesis.

The Journal of Antibiotics (2013) 66, 179-189; doi:10.1038/ja.2012.127

Keywords: atropisomer; dinapinone; structure elucidation; Talaromyces pinophilus; triacylglycerol synthesis inhibitor

\section{INTRODUCTION}

Triacylglycerol (TG) is an energy-storage molecule and thus a common form of fat found in both food and the body. TG synthesis is important in many metabolic processes in mammals, including lactation, energy storage in fat and muscle, fat absorption in the intestine and the assembly of lipoprotein particles in the liver and small intestine; however, excess accumulation of TG in certain organs and tissue causes fatty liver, obesity and hypertriglyceridemia. ${ }^{1-4}$ In the course of screening microbial metabolites for inhibitors of TG synthesis using intact Chinese hamster ovary-K1 (CHO-K1) cells, ${ }^{5}$ we discovered new dihydronaphthopyranone-containing compounds named dinapinones A1 (DPA1; 1) and A2 (DPA2; 2) and monapinones A (11) to E (15) (Figure 1) in the culture broth of Talaromyces pinophilus (originally named Penicillium pinophilum) FKI-3864..$^{5-7}$ We reported that 1 and 2, homodimers of 11 were atropisomers. Furthermore, the absolute stereochemistries of $\mathbf{1}$ and $\mathbf{2}$ were elucidated by in vitro enzymatic conversion of structure-defined 11 to 1 and $2 .^{7}$

Continuous isolation study from the culture broth of $T$. pinophilus FKI-3864 enabled us to obtain eight new dinapinones that were heterodimers of monapinones (Figure 1). In this study, the fermentation, isolation, structure elucidation and inhibitory effects on TG synthesis in CHO-K1 cells of dinapinones are described.

\section{RESULTS}

Isolation of dinapinones

Isolation procedure of dinapinones from the culture broth obtained by the fermentation of T. pinophilus FKI-3864 is shown in Figure 2 . LC/UV analysis-guided isolation of dinapinones was carried out. The 14-day-old culture broth (101) was extracted with acetone (101). After concentrating the mixture to remove acetone, the aqueous solution was adjusted to $\mathrm{pH} 3$ with $0.5 \mathrm{M} \mathrm{HCl}$ and extracted with EtOAc (101). The organic layer was dried over $\mathrm{Na}_{2} \mathrm{SO}_{4}$ and concentrated in vacuo to dryness to yield a brown material $(4.8 \mathrm{~g})$. The material was dissolved in a small amount of $\mathrm{MeOH}$ and applied to an ODS column (intradermal (i.d.) $40 \times 270 \mathrm{~mm}$; Senshu Scientific, Tokyo, Japan) and stepwise eluted with 60, 70, 80 and 90\% MeOH-0.05\% $\mathrm{H}_{3} \mathrm{PO}_{4}$ solvents (900 $\mathrm{ml}$ each).

The fractions of $90 \%$ MeOH- $0.05 \% \mathrm{H}_{3} \mathrm{PO}_{4}$ were concentrated in vacuo and extracted with EtOAc to give a brown material $(319.3 \mathrm{mg})$. This material was dissolved in $\mathrm{MeOH}$ and purified by preparative HPLC (column, CAPCELL PAK $\mathrm{C}_{18}$ UG 120 (i.d. $20 \times 250 \mathrm{~mm}$; Shiseido, Tokyo, Japan); mobile phase, $80 \% \mathrm{CH}_{3} \mathrm{CN}-$

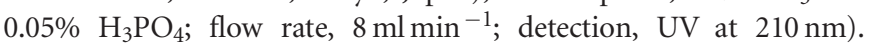
Under these conditions, dinapinones $\mathrm{A}(\mathrm{DPA})$ and $\mathrm{AB}$ (DPAB) were eluted as peaks with retention times of 14 and $17 \mathrm{~min}$, respectively. The fractions were concentrated in vacuo to dryness to give DPA

${ }^{1}$ Graduate School of Pharmaceutical Sciences, Kitasato University, Tokyo, Japan and ${ }^{2}$ Kitasato Institute for Life Sciences, Kitasato University, Tokyo, Japan Correspondence: Professor H Tomoda, Graduate School of Pharmaceutical Sciences, Kitasato University, 5-9-1 Shirokane, Minato-ku, Tokyo 108-8641, Japan. E-mail: tomodah@pharm.kitasato-u.ac.jp

Received 16 October 2012; revised 14 December 2012; accepted 18 December 2012 


\begin{tabular}{|c|c|c|}
\hline Dinapinone & Structure & $\mathrm{R}$ \\
\hline \multicolumn{3}{|l|}{ A1 (M-DPA1; 1$)$} \\
\hline \multicolumn{3}{|l|}{ A2 (P-DPA2; 2) } \\
\hline \multirow{2}{*}{\multicolumn{3}{|c|}{$\begin{array}{l}\mathrm{AB} 1(M-\mathrm{DPAB} 1 ; 3) \\
\mathrm{AB} 2(P \text {-DPAB2; } 4)\end{array}$}} \\
\hline & & \\
\hline \multirow{2}{*}{\multicolumn{3}{|c|}{ AC1 (M-DPAC1; 5) }} \\
\hline & & \\
\hline \multirow{2}{*}{\multicolumn{3}{|c|}{ AD1 (M-DPAD1; 7) }} \\
\hline & & \\
\hline \multirow{2}{*}{\multicolumn{3}{|c|}{ AE1 (M-DPAE1; 9) }} \\
\hline & & \\
\hline \multicolumn{3}{|l|}{ Monapinone } \\
\hline \multirow{2}{*}{\multicolumn{3}{|c|}{$\underbrace{\mathrm{H}}_{17} \widehat{\widehat{19}} \mathrm{CH}_{3}$}} \\
\hline & & \\
\hline \multicolumn{3}{|r|}{$\stackrel{\mathrm{OH}}{\mathrm{S}}$} \\
\hline \multicolumn{3}{|l|}{$\mathrm{B}^{\prime}\left(12^{\prime}\right)$} \\
\hline \multicolumn{3}{|r|}{ OH } \\
\hline \multicolumn{3}{|r|}{$\overbrace{13}^{\mathrm{OH}} \mathrm{OH} \mathrm{OH}_{17}$} \\
\hline$E(15)$ & & $\overbrace{13}^{\mathrm{OH}} \overbrace{15}^{\mathrm{OH}} \mathrm{OH}$ \\
\hline
\end{tabular}

Figure 1 Structures of $1-15$.

$(212.8 \mathrm{mg})$ and DPAB $(6.2 \mathrm{mg})$, both of which were a mixture of stereoisomers. As well as DPA, ${ }^{5}$ the stereoisomers of DPAB were separated by HPLC using a reverse-phase C30 column under the following conditions: column, Develosil C30 (i.d. $20 \times 250 \mathrm{~mm}$; Nomura Chemical, Aichi, Japan); mobile phase, $90 \% \mathrm{CH}_{3} \mathrm{CN}$ $0.05 \% \mathrm{H}_{3} \mathrm{PO}_{4}$; flow rate, $8 \mathrm{ml} \mathrm{min}^{-1}$; detection, $\mathrm{UV}$ at $210 \mathrm{~nm}$. Dinapinones $\mathrm{AB} 1$ (3) and $\mathrm{AB} 2$ (4) were eluted as peaks with retention times of 20 and $24 \mathrm{~min}$, respectively. These fractions were pooled and concentrated to remove $\mathrm{CH}_{3} \mathrm{CN}$. The aqueous solutions were extracted with EtOAc, and the organic layers were concentrated to dryness to give $3(1.6 \mathrm{mg})$ and $4(2.5 \mathrm{mg})$ as yellow amorphous solids.

The fractions of $80 \%$ MeOH- $0.05 \% \quad \mathrm{H}_{3} \mathrm{PO}_{4}$ were concentrated in vacuo and extracted with EtOAc to give a brown material $(217.8 \mathrm{mg})$. This material was dissolved in $\mathrm{MeOH}$ and purified by preparative HPLC (column, CAPCELL PAK C 18 UG 120 (i.d. $20 \times 250 \mathrm{~mm}$ ); mobile phase, $50 \% \mathrm{CH}_{3} \mathrm{CN}-0.05 \% \mathrm{H}_{3} \mathrm{PO}_{4}$; flow rate, $8 \mathrm{ml} \mathrm{min}^{-1}$; detection, $\mathrm{UV}$ at $\left.210 \mathrm{~nm}\right)$. Under these conditions, dinapinones AC (DPAC), AD (DPAD) and AE (DPAE) were eluted as peaks with retention times of 26,36 and $41 \mathrm{~min}$, respectively. The fractions were concentrated in vacuo to dryness to give DPAC (30.0 mg), DPAD (90.3 mg) and DPAE (7.4 mg). Similarly, to separate stereoisomers dinapinones AC1 (5) and AC2 (6), DPAC was subjected to HPLC under the following conditions: column, Develosil C30 (i.d. $20 \times 250 \mathrm{~mm}$ ); mobile phase, $50 \% \mathrm{CH}_{3} \mathrm{CN}-0.05 \% \mathrm{H}_{3} \mathrm{PO}_{4}$; flow rate, $8 \mathrm{ml} \mathrm{min}^{-1}$; detection, UV at $210 \mathrm{~nm}$. Stereoisomers 5 and 6 were eluted as peaks with retention times of 55 and $60 \mathrm{~min}$, respectively. By the same treatment, pure $5(8.6 \mathrm{mg})$ and $\mathbf{6}(9.1 \mathrm{mg})$ were obtained as yellow amorphous solids. DPAD was subjected to HPLC under the following conditions: column, Develosil C30 (i.d. $20 \times 250 \mathrm{~mm}$ ); 


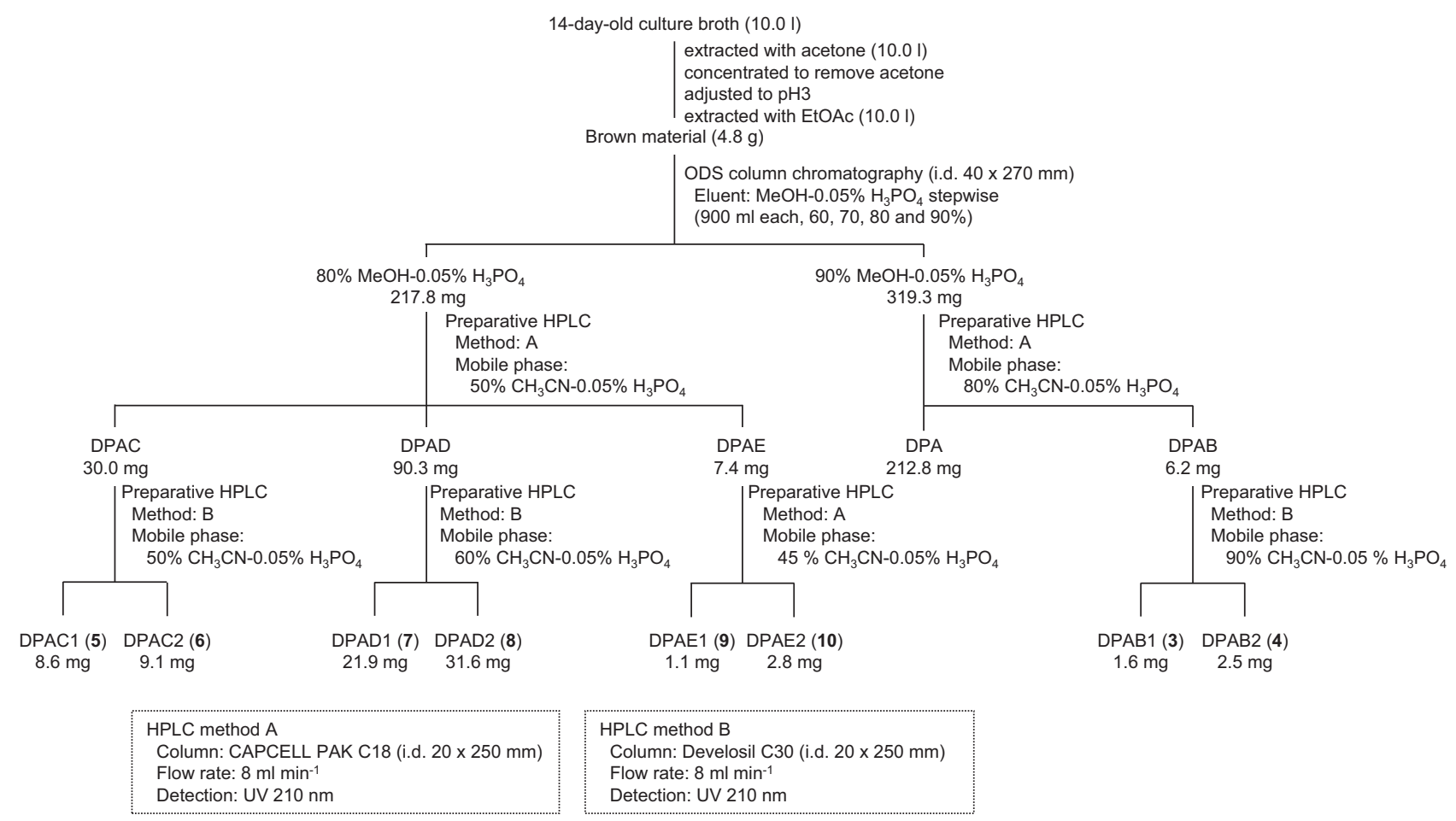

Figure 2 Isolation procedure of 3-10.

mobile phase, $60 \% \mathrm{CH}_{3} \mathrm{CN}-0.05 \% \mathrm{H}_{3} \mathrm{PO}_{4}$; flow rate, $8 \mathrm{ml} \mathrm{min}^{-1}$; detection, UV at $210 \mathrm{~nm}$. Dinapinones AD1 (7) and AD2 (8) were eluted as peaks with retention times of 28 and $30 \mathrm{~min}$, respectively. By the same treatment, pure $7(21.9 \mathrm{mg})$ and $\mathbf{8}(31.6 \mathrm{mg})$ were obtained as yellow amorphous solids. DPAE was subjected to HPLC under the following conditions: column, CAPCELL PAK $\mathrm{C}_{18}$ UG 120 (i.d. $20 \times 250 \mathrm{~mm}$ ); mobile phase, $45 \% \mathrm{CH}_{3} \mathrm{CN}-0.05 \% \mathrm{H}_{3} \mathrm{PO}_{4}$; flow rate, $8 \mathrm{ml} \mathrm{min}{ }^{-1}$; detection, UV at $210 \mathrm{~nm}$. Dinapinone AE1 (9) and AE2 (10) were eluted as peaks with retention times of 77 and $73 \mathrm{~min}$, respectively. By the same treatment, pure $\mathbf{9}(1.1 \mathrm{mg})$ and $\mathbf{1 0}(2.8 \mathrm{mg})$ were obtained as yellow amorphous solids.

\section{Physicochemical properties of dinapinones}

The physicochemical properties of dinapinones (3-10) are summarized in Table 1. The compounds had similar UV spectra with absorption maxima at 221-226, 268-269 and 382-387 nm. The IR absorption at $1637-1638,2923-2931$ and $3394-3400 \mathrm{~cm}^{-1}$ suggested the presence of a carbonyl group, alkyl chain and hydroxyl group in their structures. These data were similar to those of $\mathbf{1}$ and $2{ }^{7}$ indicating that they share the same skeleton.

\section{Structure elucidation of dinapinones}

Dinapinones AB1 (3) and AB2 (4): Dinapinone AB1 (3) showed a molecular ion peak $m / z 813[\mathrm{M}+\mathrm{Na}]^{+}$in ESI-TOF-MS, and the molecular formula $\mathrm{C}_{44} \mathrm{H}_{54} \mathrm{O}_{13}$ was assigned on the basis of its HRESITOF-MS $\left(\mathrm{m} / \mathrm{z} 813.3448(\mathrm{M}+\mathrm{Na})^{+}, \Delta-1.4 \mathrm{mmu}\right)$, indicating 18 degrees of unsaturation. The ${ }^{1} \mathrm{H}$ and ${ }^{13} \mathrm{C}$ NMR spectra of 3 (Tables 2 and 3) showed 51 protons and 44 carbons signals, which were confirmed by 2D NMR correlation. The multiplicity of the carbon signals was classified into 2 methyl carbons, 2 oxygenated methyl carbons, $13 s p^{3}$ methylate carbons, $4 s p^{2}$ methine carbons, $5 s p^{3}$ oxygenated methine carbons, $10 s p^{2}$ quaternary carbons, $6 s p^{2}$ oxygenated quaternary carbons and 2 ester carbonyl carbons by analysis of HSQC data (Table 3).

As shown by the bold lines in Figure 3, the partial structure I of 3 was elucidated by ${ }^{1} \mathrm{H}-{ }^{1} \mathrm{H}$ COSY and TOCSY spectra. ${ }^{1} \mathrm{H}-{ }^{13} \mathrm{C}$ longrange couplings of ${ }^{2} J$ and ${ }^{3} J$ in the $\mathrm{HMBC}$ are also shown in Figure 3a, leading to the following results: The cross peaks from the $s p^{3}$ oxymethine proton $\mathrm{H}-3(\delta 4.89)$ to the ester carbonyl carbon C-1 $\left(\delta\right.$ 171.28) and the $s p^{2}$ quaternary carbon C-4a $(\delta$ 132.69), from the $s p^{3}$ methylene proton $\mathrm{H}_{2}-4(\delta 3.08,3.14)$ to $\mathrm{C}-4 \mathrm{a}$, the $s p^{2}$ methine carbon C-5 $(\delta 116.23)$ and the $s p^{2}$ quaternary carbon C-10a $(\delta 99.3)$, from the $s p^{2}$ methine proton $\mathrm{H}-5\left(\delta\right.$ 6.97) to the $s p^{3}$ methylene carbon C-4 ( $\delta$ 32.99), C-4a, C-5a ( $\delta$ 140.09), the $s p^{2}$ quaternary carbon C-9a $(\delta$ 108.4) and C-10a and from OH-10 ( $\delta$ 13.71) to C-9a, the $s p^{2}$ oxygenated quaternary carbon $\mathrm{C}-10(\delta$ 162.85) and C-10a indicated the presence of a 10-oxy-3,5a,9a-trisubstituted isochroman1 -one moiety containing the partial structure I. The cross peaks from the $s p^{2}$ methine proton $\mathrm{H}-6(\delta 6.71)$ to the $s p^{2}$ oxygenated quaternary carbon C-7 $\left(\delta\right.$ 161.5), the $s p^{2}$ quaternary carbon C-8 $(\delta$ 108.2) and C-9a, from OH-9 $(\delta 9.68)$ to C-8 and the $s p^{2}$ oxygenated quaternary carbon C-9 $\left(\delta\right.$ 155.4) and from the $s p^{3}$ oxygenated methyl proton $\mathrm{H}_{3}-$ $11(\delta 3.85)$ to $\mathrm{C}-7$ indicated the presence of a 7-methoxy-9-oxy-

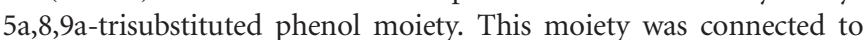
the 10-oxy-3,5a,9a-trisibstituted isochroman-1-one moiety by the cross peaks from H-5 to C-6 $(\delta$ 98.1) and from H-6 to C-5 and the ${ }^{4} J$ cross peaks from $\mathrm{H}-5$ to $\mathrm{C}-9$, from $\mathrm{H}-6$ to $\mathrm{C}-10$ and from $\mathrm{OH}-9$ to $\mathrm{C}-7$ in $\mathrm{HMBC}$ experiments, indicating the presence of the partial structure II (Figure 3), which shares the same planar structure of monapinone A (11) (named monapinone $\mathrm{A}^{\prime} ; \mathbf{1} \mathbf{1}^{\prime}$ ).

Similarly, as shown by the bold lines in Figure 3, the partial structure $\mathrm{I}^{\prime}$ was elucidated by ${ }^{1} \mathrm{H}-{ }^{1} \mathrm{H}$ COSY and TOCSY spectra. ${ }^{1} \mathrm{H}-{ }^{13} \mathrm{C}$ long-range couplings of ${ }^{2} \mathrm{~J}$ and ${ }^{3} \mathrm{~J}$ in the $\mathrm{HMBC}$ are also shown in Figure 3a, leading to the following results. Cross peaks from 
the $s p^{3}$ oxymethine proton $\mathrm{H}-3^{\prime}(\delta$ 4.86) to the ester carbonyl carbon $\mathrm{C}-1^{\prime}\left(\delta\right.$ 171.25) and the $s p^{2}$ quaternary carbon C- $4 \mathrm{a}^{\prime}(\delta$ 132.72), from the $s p^{3}$ methylene proton $\mathrm{H}_{2}-4^{\prime}(\delta 3.06,3.12)$ to $\mathrm{C}-4 \mathrm{a}^{\prime}$, the $s p^{2}$ methine carbon $\mathrm{C}-5^{\prime}\left(\delta\right.$ 116.26) and the $s p^{2}$ quaternary carbon C-10a' $\left(\delta\right.$ 99.3), from the $s p^{2}$ methine proton $\mathrm{H}-5^{\prime}\left(\delta\right.$ 6.97) to the $s p^{3}$ methylene carbon $\mathrm{C}-4^{\prime}(\delta 33.08), \mathrm{C}-4 \mathrm{a}^{\prime}$, the $s p^{2}$ quaternary carbon $\mathrm{C}-5 \mathrm{a}^{\prime}\left(\delta\right.$ 140.08), the $s p^{2}$ quaternary carbon C-9a' $(\delta$ 108.4) and $\mathrm{C}-10 \mathrm{a}^{\prime}$ and from $\mathrm{OH}-10^{\prime}\left(\delta\right.$ 13.70) to $\mathrm{C}-9 \mathrm{a}^{\prime}$, the $s p^{2}$ oxygenated quaternary carbon $\mathrm{C}-10^{\prime}(\delta 162.87)$ and $\mathrm{C}-10 \mathrm{a}^{\prime}$ indicated the presence

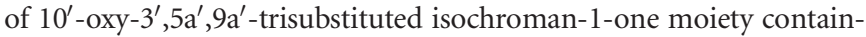
ing the partial structure $\mathrm{I}^{\prime}$. The cross peaks from the $s p^{2}$ methine proton $\mathrm{H}-6^{\prime}(\delta 6.71)$ to the $s p^{2}$ oxygenated quaternary carbon $\mathrm{C}-7^{\prime}$ $\left(\delta\right.$ 161.5), the $s p^{2}$ quaternary carbon C- $8^{\prime}(\delta$ 108.2) and C-9a', from $\mathrm{OH}-9^{\prime}\left(\delta\right.$ 9.68) to C-8 $8^{\prime}$ and the $s p^{2}$ oxygenated quaternary carbon C-9' $\left(\delta\right.$ 155.4) and from the $s p^{3}$ oxygenated methyl proton $\mathrm{H}_{3}-11^{\prime}$ $(\delta 3.85)$ to $\mathrm{C}-7^{\prime}$ indicated the presence of a $7^{\prime}$-methoxy-9'-oxy$5 \mathrm{a}^{\prime}, 8^{\prime}, 9 \mathrm{a}^{\prime}$-trisubstituted phenol moiety. The moiety was connected to the $10^{\prime}$-oxy- $3^{\prime}, 5 \mathrm{a}^{\prime}, 9 \mathrm{a}^{\prime}$-trisubstituted isochroman-1-one moiety by the cross peaks from $\mathrm{H}-5^{\prime}$ to $\mathrm{C}-6^{\prime}(\delta 98.1)$ and from $\mathrm{H}-6^{\prime}$ to $\mathrm{C}-5^{\prime}$ and the ${ }^{4} J$ cross peaks from $\mathrm{H}-5^{\prime}$ to $\mathrm{C}-9^{\prime}$, from $\mathrm{H}-6^{\prime}$ to $\mathrm{C}-10^{\prime}$ and from $9^{\prime}-\mathrm{OH}$ to $\mathrm{C}-7^{\prime}$ in $\mathrm{HMBC}$ experiments, indicating the presence of the partial structure II' (Figure 3), which shares the same planar structure of monapinone B (12) (named monapinone $\mathrm{B}^{\prime} ; \mathbf{1 2}$ ).

The chemical shifts and the molecular formula of 3 indicated that three hydroxyl groups were attached to C-13 ( $\delta$ 69.6), C-15 $(\delta 73.3)$ and $\mathrm{C}-13^{\prime}\left(\delta\right.$ 69.1). Furthermore, ${ }^{13} \mathrm{C}$ NMR chemical shift data of the partial structures II and II $^{\prime}$ were almost identical to those of $11^{\prime}$ and $12^{\prime}$, except that the methine C-8 signals $(\delta 101.2$ and $\delta 101.6)$ in $11^{\prime}$ and $12^{\prime 7}$ was replaced by quaternary carbon signal (C-8; $\delta 108.2$ and $\mathrm{C}-8^{\prime} ; \delta$ 108.2) in 3. According to the carbon signals of C-8 and C- $8^{\prime}, 3$ should have an $8,8^{\prime}$-linkage between the partial structures II and II' $^{\prime}$. This planar structure of 3 fulfilled the molecular formula and the degree of unsaturation. Thus, 3 was a heterodimer of $11^{\prime}$ and $12^{\prime}$ via an $8,8^{\prime}$-linkage.

The ${ }^{1} \mathrm{H}$ and ${ }^{13} \mathrm{C}$ NMR spectra (Tables 2 and 3 ) and 2D NMR $\left({ }^{1} \mathrm{H}-\right.$ ${ }^{1} \mathrm{H}$ COSY, HSQC and HMBC) data of 4 resembled those of 3. Accordingly, the planar structure of 4 was also elucidated to be the same as 3.

Dinapinones AC1 (5) and AC2 (6): The molecular formula of 5 is $\mathrm{C}_{46} \mathrm{H}_{58} \mathrm{O}_{16}$ on the basis of HRESI-TOF-MS $(\mathrm{m} / z$ 889.3610 $[\mathrm{M}+$ $\left.\left.\mathrm{Na}]^{+}, \Delta-1.3 \mathrm{mmu}\right)\right]$ indicating that 5 contains two more oxygen atoms than 1 . Comparison of the ${ }^{1} \mathrm{H}$ and ${ }^{13} \mathrm{C}$ NMR spectra (Tables 2 and 3$)$ between $\mathbf{1}^{7}$ and 5 indicated that the methylenes at C-17 $\left(\delta_{\mathrm{C}}\right.$ $\left.24.9, \delta_{\mathrm{H} 2} 1.30\right)$ and $\mathrm{C}-19^{\prime}\left(\delta_{\mathrm{C}} 22.6, \delta_{\mathrm{H} 2} 1.30\right)$ in 1 are replaced by the oxygenated methines at C-17 $\left(\delta_{\mathrm{C}} 70.1, \delta_{\mathrm{H}} 3.96\right)$ and $\mathrm{C}-19^{\prime}\left(\delta_{\mathrm{C}} 67.3\right.$, $\delta_{\mathrm{H}}$ 3.96) in 5, supporting the presence of monapinone $\mathrm{C}(13)$ substructure. Accordingly, 5 was a heterodimer of $\mathbf{1}^{\prime}$ and $\mathbf{1 3}$ via an $8,8^{\prime}$-linkage. (Figure 1 ), which satisfied the degrees of unsaturation and the molecular formula.

The ${ }^{1} \mathrm{H}$ and ${ }^{13} \mathrm{C}$ NMR spectra (Tables 2 and 3 ) and 2D NMR $\left({ }^{1} \mathrm{H}-{ }^{1} \mathrm{H}\right.$ COSY, HSQC and HMBC) data of $\mathbf{6}$ resembled those of $\mathbf{5}$. Accordingly, the planar structure of $\mathbf{6}$ was also elucidated to be the same as $\mathbf{5}$.

Dinapinones AD1 (7) and AD2 (8): The molecular formula of 7 is $\mathrm{C}_{44} \mathrm{H}_{54} \mathrm{O}_{15}$ on the basis of HRESI-TOF-MS $(\mathrm{m} / \mathrm{z} 845.3329(\mathrm{M}+$ $\mathrm{Na})^{+}, \Delta-3.1 \mathrm{mmu}$ ), indicating 7 contains two more oxygen atoms than 3. Comparison of the ${ }^{1} \mathrm{H}$ and ${ }^{13} \mathrm{C}$ NMR spectra (Table 2) between 3 and 7 indicated that the methylenes at C-15' $\left(\delta_{\mathrm{C}} 25.13 \delta_{\mathrm{H} 2}\right.$ $1.34)$ and $\mathrm{C}-17^{\prime}\left(\delta_{\mathrm{C}} 22.58, \delta_{\mathrm{H} 2} 1.33\right)$ in 3 are replaced by oxygenated methines at C-15' $\left(\delta_{\mathrm{C}} 70.1, \delta_{\mathrm{H}} 3.98\right)$ and $\mathrm{C}-17^{\prime}\left(\delta_{\mathrm{C}} 67.3, \delta_{\mathrm{H}} 3.97\right)$ in 7, supporting the presence of a monapinone D (14) substructure. 


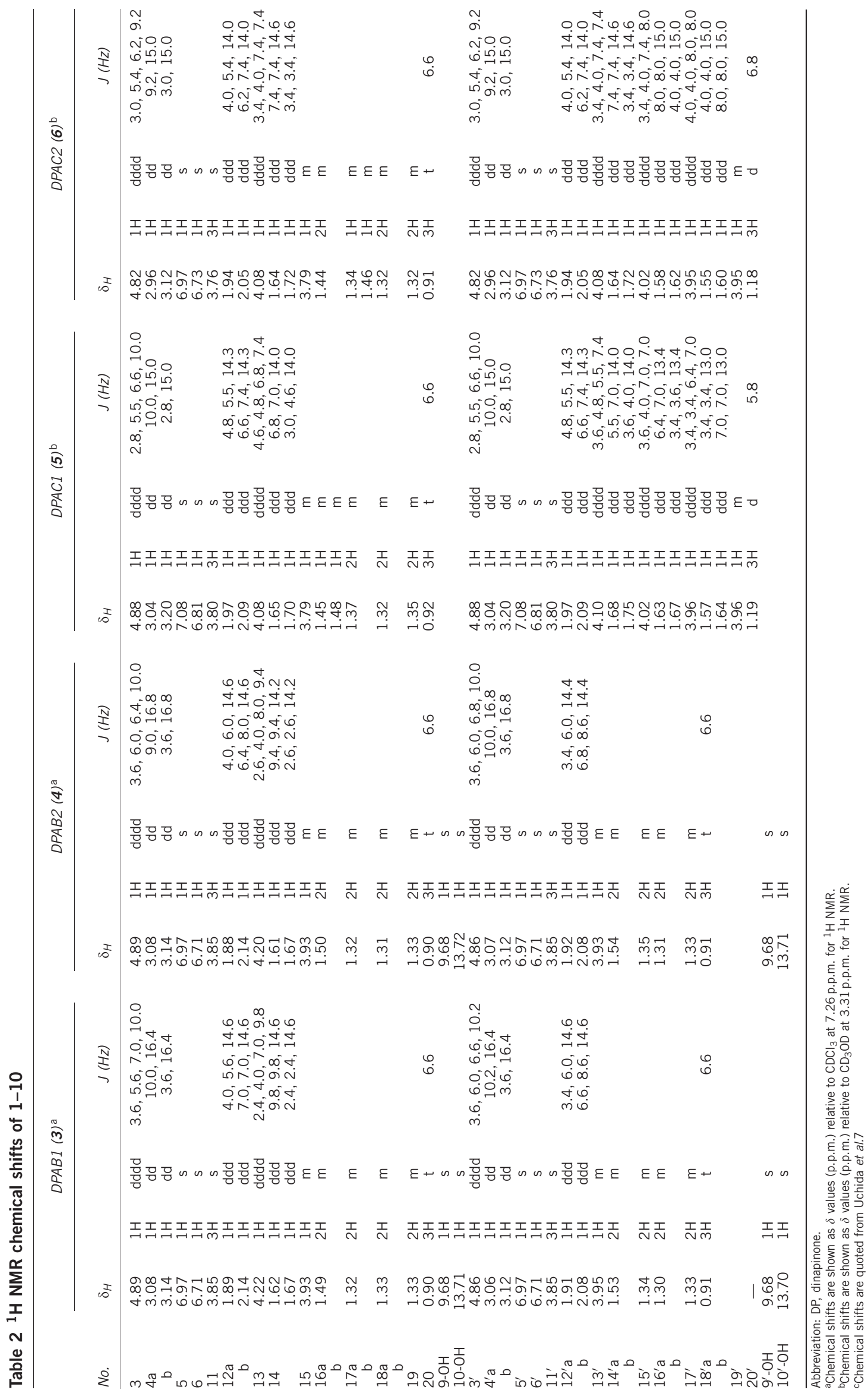




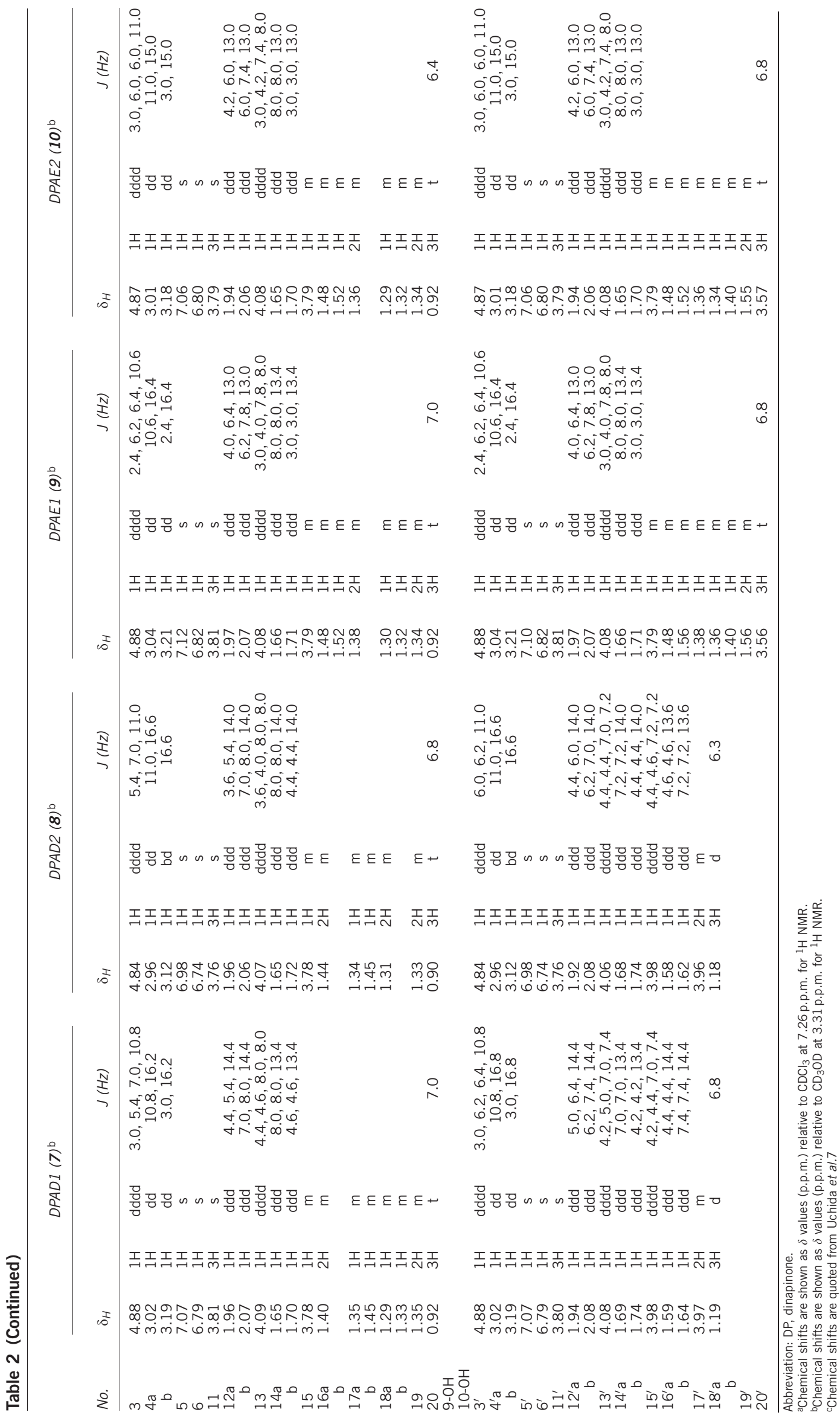




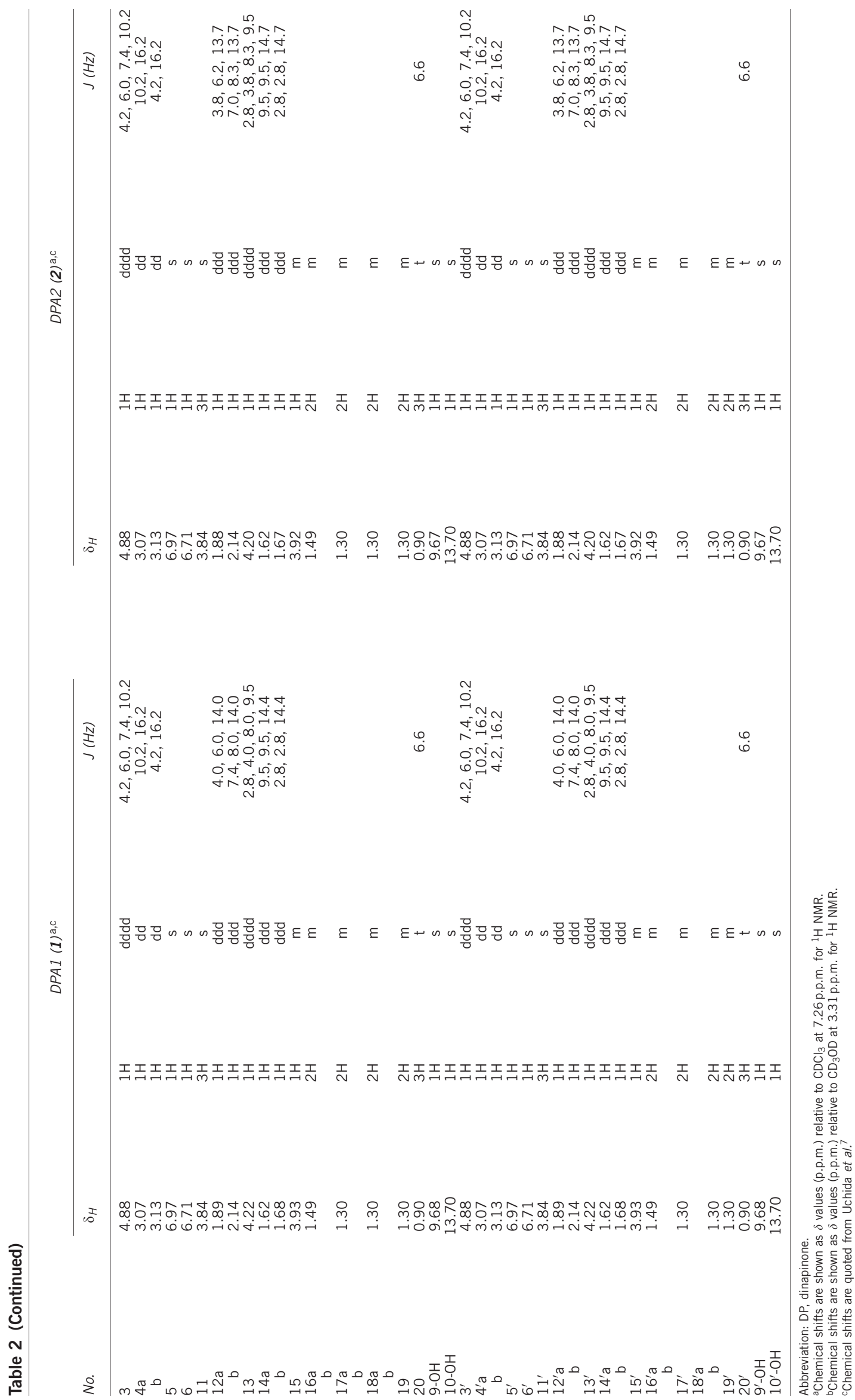


Table $3{ }^{13} \mathrm{C}$ NMR chemical shifts of $1-10$

\begin{tabular}{|c|c|c|c|c|c|c|c|c|c|c|c|c|c|c|c|c|c|c|c|c|}
\hline \multirow[b]{2}{*}{ No. } & \multicolumn{2}{|c|}{$D P A B 1(3)^{a}$} & \multicolumn{2}{|c|}{$D P B 2(4)^{\mathrm{a}}$} & \multicolumn{2}{|c|}{$D P A C 1(5)^{\mathrm{b}}$} & \multicolumn{2}{|c|}{$D P A C 2(6)^{\mathrm{b}}$} & \multicolumn{2}{|c|}{$D P A D 1(7)^{\mathrm{b}}$} & \multicolumn{2}{|c|}{ DPD2 $(\mathbf{8})^{\mathrm{b}}$} & \multicolumn{2}{|c|}{$D P A E 1(\mathbf{9})^{\mathrm{b}}$} & \multicolumn{2}{|c|}{ DPAE2 $(\mathbf{1 0})^{\mathrm{b}}$} & \multicolumn{2}{|c|}{$D P A 1(1)^{a, c}$} & \multicolumn{2}{|l|}{$D P A 2(2)^{a, c}$} \\
\hline & $\delta_{c}$ & & $\delta_{c}$ & & $\delta_{c}$ & & $\delta_{c}$ & & $\delta_{c}$ & & $\delta_{c}$ & & $\delta_{c}$ & & $\delta_{c}$ & & $\delta_{c}$ & & $\delta_{c}$ & \\
\hline 1 & 171.28 & $\mathrm{~s}$ & 171.28 & $\mathrm{~s}$ & 172.8 & $\mathrm{~s}$ & 170.8 & $\mathrm{~s}$ & 172.9 & $\mathrm{~s}$ & 172.8 & $\mathrm{~s}$ & 172.9 & $\mathrm{~s}$ & 172.8 & $\mathrm{~s}$ & 171.3 & $\mathrm{~s}$ & 171.3 & \\
\hline 3 & 78.19 & $d$ & 78.14 & $d$ & 79.3 & $d$ & 78.7 & $d$ & 79.3 & $d$ & 79.2 & $d$ & 79.3 & $d$ & 79.3 & $d$ & 78.18 & d & 78.13 & \\
\hline 4 & 32.99 & $\mathrm{t}$ & 32.85 & $\mathrm{t}$ & 33.7 & $t$ & 33.9 & $\mathrm{t}$ & 33.7 & $t$ & 33.7 & $t$ & 33.7 & $\mathrm{t}$ & 33.7 & $\mathrm{t}$ & 32.98 & $\mathrm{t}$ & 32.84 & \\
\hline $4 a$ & 132.69 & s & 132.67 & s & 134.7 & s & 133.1 & $\mathrm{~s}$ & 134.6 & $\mathrm{~s}$ & 134.5 & $\mathrm{~s}$ & 134.7 & $\mathrm{~s}$ & 134.6 & $\mathrm{~s}$ & 132.73 & $\mathrm{~s}$ & 132.7 & \\
\hline 5 & 116.23 & d & 116.24 & d & 117.5 & d & 116.5 & d & 117.6 & d & 117.6 & d & 117.6 & d & 117.6 & d & 116.26 & d & 116.28 & \\
\hline $5 a$ & 140.09 & s & 140.1 & s & 141.6 & s & 140.0 & $\mathrm{~s}$ & 141.6 & s & 141.5 & $\mathrm{~s}$ & 141.6 & s & 141.6 & $\mathrm{~s}$ & 140.1 & $\mathrm{~s}$ & 140.1 & \\
\hline 6 & 98.1 & d & 98.1 & d & 99.1 & d & 98.5 & $d$ & 99.2 & d & 99.2 & $d$ & 99.1 & $d$ & 99.2 & $d$ & 98.1 & $d$ & 98.1 & \\
\hline 7 & 161.5 & s & 161.5 & s & 162.9 & s & 161.3 & $\mathrm{~s}$ & 162.9 & s & 162.9 & $\mathrm{~s}$ & 163.0 & s & 162.9 & $\mathrm{~s}$ & 161.5 & $\mathrm{~s}$ & 161.5 & \\
\hline 8 & 108.2 & s & 108.2 & s & 109.7 & s & 108.8 & $\mathrm{~s}$ & 109.8 & s & 109.8 & $\mathrm{~s}$ & 109.8 & $\mathrm{~s}$ & 109.8 & s & 108.4 & $\mathrm{~s}$ & 108.4 & \\
\hline 9 & 155.4 & s & 155.4 & s & 156.5 & $\mathrm{~s}$ & 154.6 & $\mathrm{~s}$ & 156.3 & $\mathrm{~s}$ & 154.3 & $\mathrm{~s}$ & 156.4 & $\mathrm{~s}$ & 156.3 & $\mathrm{~s}$ & 155.4 & $\mathrm{~s}$ & 155.4 & \\
\hline $9 a$ & 108.4 & $\mathrm{~s}$ & 108.5 & $\mathrm{~s}$ & 109.4 & $\mathrm{~s}$ & 108.2 & $\mathrm{~s}$ & 109.3 & $\mathrm{~s}$ & 109.2 & $\mathrm{~s}$ & 109.3 & $\mathrm{~s}$ & 109.3 & $\mathrm{~s}$ & 108.2 & $\mathrm{~s}$ & 108.2 & \\
\hline 10 & 162.85 & $\mathrm{~s}$ & 162.84 & $\mathrm{~s}$ & 162.9 & $\mathrm{~s}$ & 161.0 & $\mathrm{~s}$ & 163.3 & $\mathrm{~s}$ & 162.9 & $\mathrm{~s}$ & 163 & $\mathrm{~s}$ & 163 & $\mathrm{~s}$ & 162 & $\mathrm{~s}$ & .82 & \\
\hline $10 a$ & 99.3 & $\mathrm{~s}$ & 99.4 & s & 100.7 & $\mathrm{~s}$ & 99.6 & $\mathrm{~s}$ & 100.6 & $\mathrm{~s}$ & 100.5 & $\mathrm{~s}$ & 100.7 & $\mathrm{~s}$ & 100.6 & $\mathrm{~s}$ & 99.3 & $\mathrm{~s}$ & 99.3 & \\
\hline 11 & 56.0 & $q$ & 56.0 & $q$ & 56.2 & $q$ & 56.2 & $q$ & 56.2 & $q$ & 56.3 & $q$ & 56.2 & $q$ & 56.2 & $q$ & 55.9 & $q$ & 55.9 & \\
\hline 12 & 42.2 & $\mathrm{t}$ & 42.1 & $\mathrm{t}$ & 43.1 & $\mathrm{t}$ & 43.2 & $t$ & 43.1 & $t$ & 43.1 & $t$ & 43.0 & $\mathrm{t}$ & 43.1 & $t$ & 42.25 & $t$ & 42.14 & \\
\hline 13 & 69.6 & $d$ & 69.6 & d & 67.7 & d & 67.4 & $d$ & 67.6 & $d$ & 67.7 & $d$ & 68.0 & $d$ & 68.0 & $d$ & 69.6 & $d$ & 69.54 & \\
\hline 14 & 42.9 & $\mathrm{t}$ & 42.9 & $\mathrm{t}$ & 45.6 & $\mathrm{t}$ & 45.6 & $\mathrm{t}$ & 44.9 & $\mathrm{t}$ & 44.9 & $\mathrm{t}$ & $44.92^{\mathrm{d} 1}$ & $\mathrm{t}$ & 44.9 & $\mathrm{t}$ & & $\mathrm{t}$ & 42.91 & \\
\hline 15 & 73.3 & $d$ & 73.4 & d & 71.3 & $d$ & 71.0 & $d$ & 71.3 & $d$ & 71.4 & $d$ & $71.29 \mathrm{~d} 2$ & $d$ & $71.21^{\mathrm{d} 5}$ & $d$ & 73.36 & $d$ & 73.36 & \\
\hline 16 & 38.4 & $\mathrm{t}$ & 38.4 & $\mathrm{t}$ & 38.8 & $t$ & 39.0 & $t$ & 38.8 & $t$ & 38.8 & $\mathrm{t}$ & $38.76^{\mathrm{d} 3}$ & $\mathrm{t}$ & $38.74^{\mathrm{d} 6}$ & $\mathrm{t}$ & 38.38 & $\mathrm{t}$ & 38.4 & \\
\hline 17 & 24.94 & $\mathrm{t}$ & 24.9 & $\mathrm{t}$ & 26.2 & $\mathrm{t}$ & 26.6 & $\mathrm{t}$ & 26.3 & $\mathrm{t}$ & 26.3 & $\mathrm{t}$ & $26.34^{\mathrm{d} 4}$ & $\mathrm{t}$ & $26.22^{\mathrm{d} 7}$ & $\mathrm{t}$ & 24.9 & $\mathrm{t}$ & 24.9 & \\
\hline 18 & 31.73 & $\mathrm{t}$ & 31.7 & $\mathrm{t}$ & 33.1 & $\mathrm{t}$ & 33.4 & $\mathrm{t}$ & 33.1 & $\mathrm{t}$ & 33.1 & $\mathrm{t}$ & 33.1 & $\mathrm{t}$ & 33.1 & $\mathrm{t}$ & 31.7 & $\mathrm{t}$ & 31.7 & \\
\hline 19 & 22.61 & $\mathrm{t}$ & 22.60 & $\mathrm{t}$ & 23.7 & $\mathrm{t}$ & 24.2 & $\mathrm{t}$ & 23.8 & $\mathrm{t}$ & 23.8 & $\mathrm{t}$ & 23.7 & $\mathrm{t}$ & 23.7 & $\mathrm{t}$ & 22.6 & $\mathrm{t}$ & 22.6 & \\
\hline 20 & 14.00 & q & 14.00 & $q$ & 14.4 & $q$ & 15.0 & $q$ & 14.4 & $q$ & 14.4 & $q$ & 14.4 & $q$ & 14.4 & $q$ & 14.0 & $q$ & 14.0 & \\
\hline $1^{\prime}$ & 171.25 & s & 171.24 & s & 172.8 & s & 170.8 & s & 172.9 & s & 172.8 & s & 172.9 & s & 172.8 & s & 171.3 & s & 171.3 & \\
\hline $3^{\prime}$ & 8.81 & d & 78.77 & $d$ & 79.3 & $d$ & 78.7 & $d$ & 79.3 & $d$ & 79.2 & $d$ & 79.3 & $d$ & 79.3 & $d$ & 78.18 & $d$ & 78.13 & \\
\hline $4^{\prime}$ & 33.08 & $\mathrm{t}$ & 33.0 & $\mathrm{t}$ & 33.7 & $\mathrm{t}$ & 33.9 & $\mathrm{t}$ & 33.7 & $\mathrm{t}$ & 33.7 & $\mathrm{t}$ & 33.7 & $\mathrm{t}$ & 33.7 & $\mathrm{t}$ & 32.98 & $\mathrm{t}$ & 32.84 & \\
\hline $4 a^{\prime}$ & 132.72 & $\mathrm{~s}$ & 132.71 & $\mathrm{~s}$ & 134.7 & $\mathrm{~s}$ & 133.1 & $\mathrm{~s}$ & 134.6 & $\mathrm{~s}$ & 134.5 & $\mathrm{~s}$ & 134.7 & $\mathrm{~s}$ & 134.6 & $\mathrm{~s}$ & 132.73 & $\mathrm{~s}$ & 132.7 & \\
\hline $5^{\prime}$ & 116.26 & d & 116.28 & $d$ & 117.5 & $d$ & 116.5 & $d$ & 7.6 & $d$ & 117.6 & $d$ & 117.6 & $d$ & 117.6 & $d$ & 116.26 & $d$ & 116.28 & \\
\hline $5 a^{\prime}$ & 140.08 & $\mathrm{~s}$ & 140.1 & s & 141.6 & s & 140.0 & $\mathrm{~s}$ & 141.6 & $\mathrm{~s}$ & 141.5 & $\mathrm{~s}$ & & s & & $\mathrm{s}$ & 140 & $\mathrm{~s}$ & 140.1 & \\
\hline $6^{\prime}$ & 98.1 & $d$ & 98.1 & d & 99.1 & $d$ & 98.5 & $d$ & 99.2 & $d$ & 99.2 & $d$ & 99.1 & $d$ & 99.2 & $d$ & 98.1 & d & 98.1 & \\
\hline $7^{\prime}$ & 161.5 & $\mathrm{~s}$ & 161.5 & s & 162.9 & $\mathrm{~s}$ & 161.3 & $\mathrm{~s}$ & 162.9 & $\mathrm{~s}$ & 162.9 & $\mathrm{~s}$ & 163.0 & $\mathrm{~s}$ & 162.9 & $\mathrm{~s}$ & 161.5 & $\mathrm{~s}$ & 161.5 & \\
\hline $8^{\prime}$ & 108.2 & $\mathrm{~s}$ & 108.2 & $\mathrm{~s}$ & 109.7 & $\mathrm{~s}$ & 108.8 & $\mathrm{~s}$ & 109.8 & $\mathrm{~s}$ & 109.8 & $\mathrm{~s}$ & 109.8 & $\mathrm{~s}$ & 109.8 & $\mathrm{~s}$ & 108.4 & $\mathrm{~s}$ & 108.4 & \\
\hline $9^{\prime}$ & 155.4 & $\mathrm{~s}$ & 155.4 & s & 156.5 & $\mathrm{~s}$ & 154.6 & $\mathrm{~s}$ & 156.3 & $\mathrm{~s}$ & 154.3 & $\mathrm{~s}$ & 156.4 & $\mathrm{~s}$ & 156.3 & $\mathrm{~s}$ & 155.4 & $\mathrm{~s}$ & 155.4 & \\
\hline $9 a^{\prime}$ & 108.4 & $\mathrm{~s}$ & 108.5 & s & 109.4 & $\mathrm{~s}$ & 108.2 & $\mathrm{~s}$ & 109.3 & $\mathrm{~s}$ & 109.2 & $\mathrm{~s}$ & 109.3 & $\mathrm{~s}$ & 109.3 & $\mathrm{~s}$ & 108.2 & $\mathrm{~s}$ & 108.2 & \\
\hline $10^{\prime}$ & 162.87 & s & 162.87 & $\mathrm{~s}$ & 162.9 & s & 161.0 & $\mathrm{~s}$ & 163.3 & s & 162.9 & $\mathrm{~s}$ & 163.4 & s & 163.3 & s & 162.9 & $\mathrm{~s}$ & 162.82 & \\
\hline $10 a^{\prime}$ & 99.3 & $\mathrm{~s}$ & 99.4 & s & 100.7 & $\mathrm{~s}$ & 99.6 & $\mathrm{~s}$ & 100.6 & $\mathrm{~s}$ & 100.5 & $\mathrm{~s}$ & 100.7 & $\mathrm{~s}$ & 100.6 & $\mathrm{~s}$ & 99.3 & $\mathrm{~s}$ & 99.3 & \\
\hline $11^{\prime}$ & 56.0 & $q$ & 56.0 & $q$ & 56.2 & $q$ & 56.2 & $q$ & 56.2 & $q$ & 56.3 & $q$ & 56.2 & $q$ & 56.2 & $q$ & 55.9 & $q$ & 55.9 & \\
\hline $12^{\prime}$ & 41.9 & $\mathrm{t}$ & 41.8 & $\mathrm{t}$ & 43.1 & $\mathrm{t}$ & 43.2 & $\mathrm{t}$ & 43.1 & $\mathrm{t}$ & 43.1 & $\mathrm{t}$ & 43.0 & $\mathrm{t}$ & 43.1 & $\mathrm{t}$ & 42.25 & $\mathrm{t}$ & 42.14 & \\
\hline $13^{\prime}$ & 69.1 & $d$ & 69.0 & d & 68.0 & $d$ & 67.7 & $d$ & 68.0 & $d$ & 68.0 & $d$ & 68.0 & $d$ & 68.0 & $d$ & 69.6 & $d$ & 69.54 & \\
\hline $14^{\prime}$ & 37.7 & $\mathrm{t}$ & 37.8 & $\mathrm{t}$ & 44.9 & $\mathrm{t}$ & 45.1 & $\mathrm{t}$ & 45.2 & $\mathrm{t}$ & 45.2 & $\mathrm{t}$ & $44.91^{\mathrm{d} 1}$ & $\mathrm{t}$ & 44.9 & $\mathrm{t}$ & 42.91 & $\mathrm{t}$ & 42.91 & \\
\hline $15^{\prime}$ & 25.13 & $\mathrm{t}$ & 25.1 & $\mathrm{t}$ & 69.9 & $d$ & 69.7 & $d$ & 70.1 & $d$ & 70.2 & d & $71.18^{\mathrm{d} 2}$ & $d$ & $71.32^{\mathrm{d} 5}$ & $d$ & 73.36 & d & 73.36 & \\
\hline $16^{\prime}$ & 31.74 & $\mathrm{t}$ & 31.7 & $\mathrm{t}$ & 45.1 & $\mathrm{t}$ & 45.6 & $\mathrm{t}$ & 47.0 & $t$ & 47.0 & $t$ & $38.74^{\mathrm{d} 3}$ & $\mathrm{t}$ & $38.77^{\mathrm{d} 6}$ & $\mathrm{t}$ & 38.38 & $\mathrm{t}$ & 38.4 & \\
\hline $17^{\prime}$ & 22.58 & $\mathrm{t}$ & 22.6 & $\mathrm{t}$ & 70.1 & $d$ & 69.8 & $d$ & 67.3 & $d$ & 67.3 & $d$ & $26.23^{\mathrm{d} 4}$ & $\mathrm{t}$ & $26.34^{\mathrm{d} 7}$ & $\mathrm{t}$ & 24.9 & $\mathrm{t}$ & 24.9 & \\
\hline $18^{\prime}$ & 14.01 & $q$ & 14.01 & $q$ & 46.9 & $\mathrm{t}$ & 46.9 & $\mathrm{t}$ & 23.7 & $q$ & 23.7 & $q$ & 27.0 & $\mathrm{t}$ & 27.0 & $\mathrm{t}$ & 31.7 & $\mathrm{t}$ & 31.7 & \\
\hline $19^{\prime}$ & - & & - & - & 67.3 & $d$ & 67.1 & $d$ & - & - & & & 33.6 & $\mathrm{t}$ & 33.6 & $\mathrm{t}$ & 22.6 & $\mathrm{t}$ & 22.6 & \\
\hline $20^{\prime}$ & - & & - & - & 23.7 & $q$ & 24.2 & $q$ & - & - & & & 63.0 & $\mathrm{t}$ & 63.0 & $\mathrm{t}$ & 14.0 & $q$ & 14.0 & \\
\hline
\end{tabular}

Abbreviation: DP, dinapinone.

${ }^{a}$ Chemical shifts are shown as $\delta$ values (p.p.m.) relative to $\mathrm{CDCl}_{3}$ at 77.0 p.p.m. for ${ }^{13} \mathrm{C} \mathrm{NMR}$.

${ }^{b}$ Chemical shifts are shown as $\delta$ values (p.p.m.) relative to $\mathrm{CD}_{3} \mathrm{OD}$ at 49.0 p.p.m. for ${ }^{13} \mathrm{C} \mathrm{NMR}$

${ }^{\mathrm{C} C h e m i c a l ~ s h i f t s ~ a r e ~ q u o t e d ~ f r o m ~ U c h i d a ~ e t ~ a l . ~}$

${ }^{\mathrm{d}}$ Chemical shifts are exchangeable.

Accordingly, 7 was a heterodimer of $1 \mathbf{1}^{\prime}$ and $\mathbf{1 4}$ via an $8,8^{\prime}$-linkage (Figure 1), which satisfied the degrees of unsaturation and the molecular formula.

The ${ }^{1} \mathrm{H}$ and ${ }^{13} \mathrm{C}$ NMR spectra (Tables 2 and 3 ) and 2D NMR $\left({ }^{1} \mathrm{H}-{ }^{1} \mathrm{H}\right.$ COSY, HSQC and HMBC) data of $\mathbf{8}$ resembled those of 7. Accordingly, the planar structure of $\mathbf{8}$ was also elucidated to be the same as $\mathbf{7}$.
Dinapinones AE1 (9) and AE2 (10): the molecular formula of 9 is $\mathrm{C}_{46} \mathrm{H}_{58} \mathrm{O}_{15}$ on the basis of HRESI-TOF-MS $(\mathrm{m} / \mathrm{z} 873.3668(\mathrm{M}+$ $\mathrm{Na})^{+}, \Delta-0.5 \mathrm{mmu}$ ), indicating that 9 contains one more oxygen atom than 1. Comparison of the ${ }^{1} \mathrm{H}$ and ${ }^{13} \mathrm{C}$ NMR spectra (Table 2) between 1 and 9 indicated that the methyl at C-20' $\left(\delta_{\mathrm{C}} 14.0, \delta_{\mathrm{H} 3} 0.90\right)$ in 1 are replaced by the oxygenated methylene at $\mathrm{C}-20^{\prime}\left(\delta_{\mathrm{C}} 63.0, \delta_{\mathrm{H} 2}\right.$ 


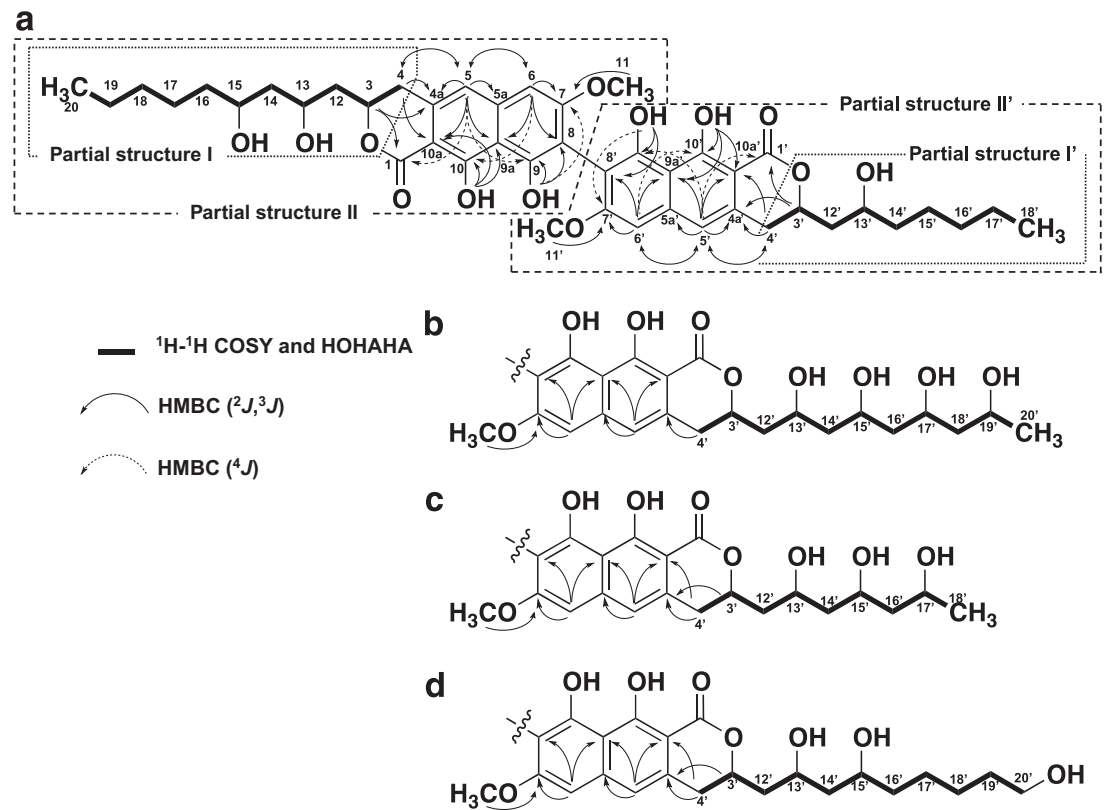

Figure $\mathbf{3}$ Structure elucidations of $\mathbf{3}-\mathbf{1 0}$ by ${ }^{1} \mathrm{H}-{ }^{1} \mathrm{H}$ COSY, TOCSY and HMBC experiments. (a) Compounds $\mathbf{3}$ and $\mathbf{4}$, (b) $\mathbf{5}$ and $\mathbf{6}$, (c) $\mathbf{7}$ and $\mathbf{8}$, and (d) $\mathbf{9}$ and 10.
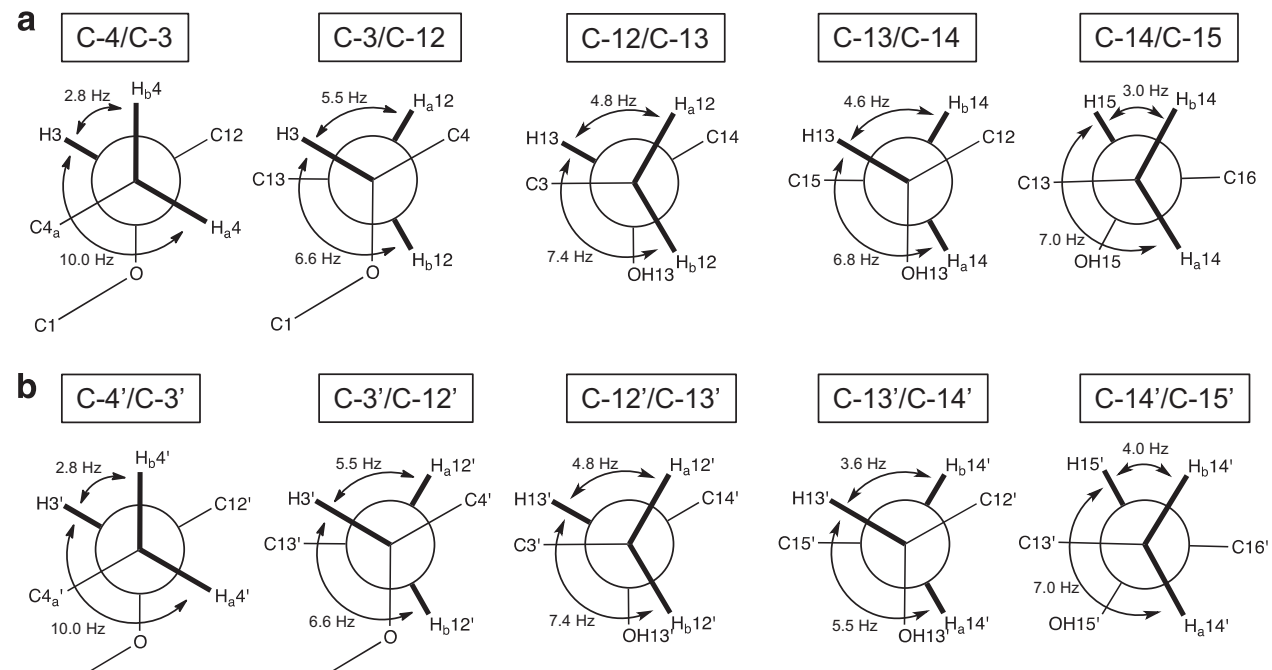

C1'
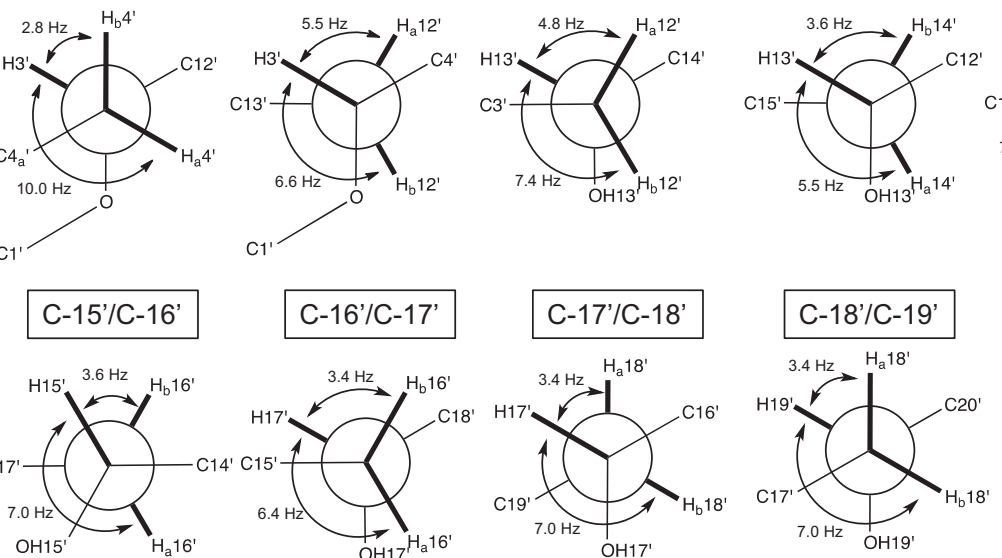

Figure 4 Coupling constants $\left({ }^{2} J_{\mathrm{HH}}\right)$ and the dihedral angles of partial structures $\mathrm{I}(\mathbf{a})$ and $\mathrm{I}^{\prime}(\mathbf{b})$ of $\mathbf{5}$.

3.56) in 9, supporting the presence of monapinone E (15) substructure. Accordingly, 9 was a heterodimer of $11^{\prime}$ and 15 via an $8,8^{\prime}-$ linkage (Figure 1), which satisfied the degrees of unsaturation and the molecular formula.

The ${ }^{1} \mathrm{H}$ and ${ }^{13} \mathrm{C}$ NMR spectra (Tables 2 and 3$)$ and 2D NMR $\left({ }^{1} \mathrm{H}-\right.$ ${ }^{1} \mathrm{H}$ COSY, HSQC and HMBC) data of $\mathbf{1 0}$ resembled those of $\mathbf{9 .}$ Accordingly, the planar structure of $\mathbf{1 0}$ was also elucidated to be the same as 9.

\section{Relative stereochemistries of dinapinones}

From the planar structure elucidation, all dinapinones (3-10) were heterodimers of one $11^{\prime}$ and one different monapinone $\left(12^{\prime}, 13-15\right)$. Compounds 5 and 6 , consisting of $11^{\prime}$ and 13 , have eight chiral carbons. The relative stereochemistry of the $\mathbf{1 1}^{\prime}$ substructure in 5 was elucidated by analysis of the dihedral angles (Figure 4), ${ }^{1} \mathrm{H}$ NMR coupling constants ( $J$ values) and ROESY experiments (Figure 5). The large value of $J_{3-4 a x i a l}(10.0 \mathrm{~Hz})$ indicated that the two protons 


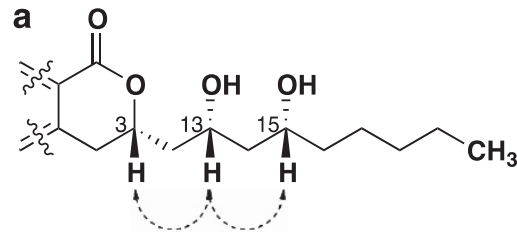

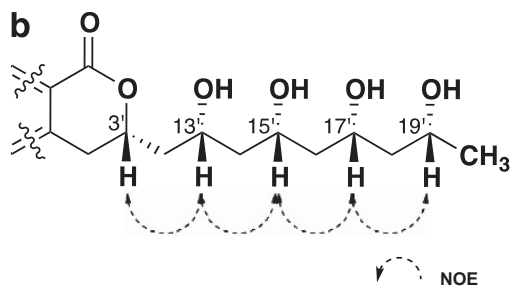

Figure 5 ROESY experiments of partial structures I (a) and $I^{\prime}$ (b) of 5.

Table 4 Effects of CE and TG synthesis of $1-10$ in CHO-K1 cells

\begin{tabular}{lcccc}
\hline & \multicolumn{3}{c}{ C $_{50}(\mu \mathrm{M})$} & \\
\cline { 2 - 4 } Dinapinone & $C E$ & $T G$ & $P L$ & $\begin{array}{c}\text { Selectivity index } \\
\text { CE/TG }\end{array}$ \\
\hline A1 (1) & $>12$ & $>12$ & $>12$ & - \\
A2 (2) & 2.94 & 0.87 & $>12$ & 3.38 \\
AB1 (3) & $>12$ & $>12$ & $>12$ & - \\
AB2 (4) & 10.16 & 1.17 & $>12$ & 8.68 \\
AC1 (5) & $>12$ & $>12$ & $>12$ & - \\
AC2 (6) & $>12$ & $>12$ & $>12$ & - \\
AD1 (7) & $>12$ & $>12$ & $>12$ & - \\
AD2 (8) & $>12$ & 8.94 & $>12$ & $>1.34$ \\
AE1 (9) & $>12$ & 9.19 & $>12$ & $>1.31$ \\
AE2 (10) & $>12$ & 9.34 & $>12$ & $>1.28$ \\
\hline
\end{tabular}

Abbreviations: CE, cholesterol ester; PL, phospholipid; TG, triacylglycerol.

were in trans diaxial orientation at C-3. As for a dihydroxyalkyl chain at C-13 and C-15 of the $\mathbf{1 1}^{\prime}$ substructure in 5 , NOEs were observed between $\mathrm{H}-3(\delta 4.88)$ and $\mathrm{H}-13(\delta 4.08)$ and between $\mathrm{H}-13$ and H-15 ( $\delta$ 3.79) (Figure 5). Additionally, the coupling constants (Table 2) and the dihedral angles (Figure 4) from C-12 to C-15 were similar to those of $11^{\prime}, 7$ indicating that the $\mathbf{1 1}^{\prime}$ substructure in 5 had the same configuration of $\mathbf{1 1}$. Thus, the relative stereochemistry of the $11^{\prime}$ substructure in 5 was elucidated to be $3 S^{\star} 13 R^{\star} 15 R^{\star}$. The relative stereochemistry of the $\mathbf{1 3}$ substructure in $\mathbf{5}$ was elucidated similarly. The large value of $J_{3^{\prime}-4^{\prime} \text { axial }}(10.0 \mathrm{~Hz})$ indicated that the two protons were also in trans diaxial orientation at C-3. As for a tetrahydroxyalkyl chain at $\mathrm{C}-13^{\prime}, \mathrm{C}-15^{\prime}, \mathrm{C}-17^{\prime}$ and $\mathrm{C}-19^{\prime}$ of the 13 substructure in 5, NOEs were observed between $\mathrm{H}-3^{\prime}\left(\begin{array}{l} \\ \end{array}\right.$ 4.88) and $\mathrm{H}-13^{\prime}\left(\delta\right.$ 4.10), $\mathrm{H}-13^{\prime}$ and $\mathrm{H}-15^{\prime}\left(\delta\right.$ 4.02) and $\mathrm{H}-15^{\prime}$ and $\mathrm{H}-17^{\prime}\left(\delta\right.$ 3.96) (Figure 5). Additionally, the ${ }^{1} \mathrm{H}$ NMR coupling constants (Table 2) and the dihedral angles (Figure 4) from C-12' to $\mathrm{C}-19^{\prime}$ supported that the four hydroxy groups were all in syn configuration. Thus, the relative stereochemistry of the $\mathbf{1 3}$ substructure in 5 was elucidated to be $3^{\prime} S^{\star} 13^{\prime} R^{\star} 15^{\prime} R^{\star} 17^{\prime} R^{\star} 19^{\prime} R^{\star}$. Taking all these findings together, the relative stereochemistry of 5 was elucidated as shown in Figure 1.

The ${ }^{1} \mathrm{H}$ NMR coupling constants and ROESY experimental data of 6 resembled those of 5 (Table 2). Accordingly, the relative stereochemistry of 6 was elucidated to be $3 S^{\star} 13 R^{\star} 15 R^{\star} 3^{\prime} S^{\star} 13^{\prime} R^{\star} 15^{\prime} R^{\star}$ $17^{\prime} R^{\star} 19^{\prime} R^{\star}$. Thus, heterodimers 5 and $\mathbf{6}$, consisting of 11 and $\mathbf{1 3}$, have the same relative stereochemistries, suggesting that they are atropisomers.

The relative stereochemistries of the three pairs of stereoisomers 3 and 4, 7 and 8 , and 9 and 10 were also defined to be $3 S^{\star} 13 R^{\star} 15 R^{\star}$ $3^{\prime} S^{\star} 13^{\prime} R^{\star}, 3 S^{\star} 13 R^{\star} 15 R^{\star} 3^{\prime} S^{\star} 13^{\prime} R^{\star} 15^{\prime} R^{\star} 17^{\prime} R^{\star}$ and $3 S^{\star} 13 R^{\star} 15 R^{\star} 3^{\prime} S^{\star}$ $13^{\prime} R^{\star} 15^{\prime} R^{\star}$, respectively, from the same analysis of the coupling constants in ${ }^{1} \mathrm{H}$ NMR and ROESY experiments. Each pair (3 and 4, 5 and 6, 7 and 8, and 9 and 10) was deduced to be atropisomers from the similar relation of $\mathbf{1}$ and $\mathbf{2}$ as reported previously.

\section{Absolute axis configurations of dinapinones}

To elucidate the absolute axis configuration, the CD data of 3-10 were compared with those of $(M)-1$ and $(P)-2 .{ }^{7}$ Compounds 3, 5, 7 and 9 exhibited the first negative cotton effect at $284-287 \mathrm{~nm}$ and the second positive cotton effect at $247-250 \mathrm{~nm}$ in the CD spectrum (Table 1). On the other hand, 4, 6, 8 and 10 exhibited the first positive cotton effect at $275-285 \mathrm{~nm}$ and the second negative cotton effect at 245-257 $\mathrm{nm}$ in the CD spectrum (Table 1). These spectra were almost identical to those of $\mathbf{1}$ and 2, respectively. Accordingly, the absolute axis configurations of $\mathbf{3}, 5,7$ and $\mathbf{9}$ were elucidated to be $M$ and those of $4,6,8$ and 10 were $P$.

\section{Inhibition of TG and CE synthesis by dinapinones}

The effect of dinapinones (3-10) was evaluated on the synthesis of $\left[{ }^{14} \mathrm{C}\right] \mathrm{TG}$ and $\left[{ }^{14} \mathrm{C}\right] \mathrm{CE}$ from $\left[{ }^{14} \mathrm{C}\right]$ oleic acid in $\mathrm{CHO}-\mathrm{K} 1$ cells. Compounds $\mathbf{1}$ and $\mathbf{2}$ were also tested for comparative purposes. The $\mathrm{IC}_{50}$ values are summarized in Table 4. Among the dinapinones, 2 showed the most potent inhibition of TG synthesis with an $\mathrm{IC}_{50}$ value of $0.87 \mu \mathrm{M}$, which was comparable with the value $(0.65 \mu \mathrm{M})$ previously reported. ${ }^{7}$ Compound $\mathbf{4}$ exhibited the second most potent inhibition $\left(\mathrm{IC}_{50}, 1.17 \mu \mathrm{M}\right.$ ), followed by $\mathbf{8}, 9$ and 10 ( $\mathrm{IC}_{50}$, $8.9 \sim 9.3 \mu \mathrm{M})$. The other dinapinones $(\mathbf{1}, 3,5,6$ and 7$)$ showed very weak or no activity at $12 \mu \mathrm{M}$. Active dinapinones $(2,4,8,9$ and 10) were found to inhibit cholesterol ester (CE) synthesis, but to have selectivity toward the inhibition of TG synthesis (selectivity index, 1.3-8.7)

\section{DISCUSSION}

In this study, eight new dinapinones (3-10) were purified by LC/UV analysis-guided isolation from the culture broth of $T$. pinophilus. From the structure elucidation, $\mathbf{3 - 1 0}$ were found to be heterodimers consisting of monapinone A (11), and the other monapinones $(12-15)$ and pairs of 3 and 4, 5 and 6, 7 and 8, and 9 and 10 were atropisomers. The relative stereochemistries of monapinone substructures in dinapinones were elucidated by precise analyses of the dihedral angles, $J$ values and ROESY experiments (Figures 4 and 5). In the previous study, the stereochemistries of 13-15 were not elucidated, but we confirmed that they are the same as the corresponding substructures in dinapinones (data not shown). These findings indicated that dinapinones are biosynthesized from monapinones.

Considering the axis configuration, there are 2 atropisomers for this series of homodimers. In fact, atropisomers $\mathbf{1}$ and $\mathbf{2}$ were obtained as homodimers of monapinone A (11).$^{5-7}$ In the case of a heterodimer, two monomers can link in two different fashions, that is, monomer A-monomer B or monomer B-monomer A, and each heterodimer should have two atropisomers. Thus, there are theoretically four different structures to a heterodimer. Among them, however, a pair of atropisomers was obtained for each dinapinones in this study. This might be due to the characteristics of the 
hypothetical dimerization enzyme in this fungal strain. It therefore appeared difficult to elucidate the complete stereochemistry of the two atropisomers, but this could be achieved by X-ray crystallographic analysis.

Regarding the biological activity of dinapinones, 2 and $\mathbf{4}$ showed potent TG inhibition in $\mathrm{CHO}-\mathrm{K} 1$ cells and moderate $\mathrm{CE}$ inhibition, resulting in low selectivity indexes (3.4 and 8.7, respectively) (Table 4). Other dinapinones are not such potent inhibitors of TG synthesis. In the previous study, we reported that the 1:1 mixture of 1 and $\mathbf{2}$ increased inhibitory activity against TG synthesis and selectivity toward TG synthesis. ${ }^{5}$ Evaluation of the 1:1 mixture of each atropisomers in this TG synthesis assay using $\mathrm{CHO}-\mathrm{K} 1$ cells is ongoing, and the results will be described elsewhere.

\section{METHODS}

\section{General experimental procedure}

SSC-ODS-7515-12 (Senshu Scientific) was used for ODS column chromatography. Various NMR spectra were obtained using NMR System $400 \mathrm{MHz}$ and an INOVA $600 \mathrm{MHz}$ spectrometer (Agilent Technologies, Santa Clara, CA, USA). ESI-MS spectrometry was conducted using a JMS-T100LP spectrometer (JEOL, Tokyo, Japan). Optical rotation and CD were recorded on a JASCO model DIP-181 polarimeter (JASCO, Tokyo, Japan) and J-720 CD spectrometer (JASCO). UV and IR spectra were measured with a Beckman DU640 spectrophotometer (Beckman Coulter, Fullerton, CA, USA) and FT-210 Fourier transform IR spectrometer (HORIBA, Kyoto, Japan), respectively.

\section{Microorganism}

Fungal strain T. pinophilus FKI-3864 was isolated from a soil sample collected Hilo, Hawaii, USA. This strain was used to produce dinapinones. ${ }^{5}$

\section{Fermentation}

A slant culture of strain FKI-3864 grown on Miura's medium $(0.10 \%$ glycerol, $0.08 \% \mathrm{KH}_{2} \mathrm{PO}_{4}, 0.02 \% \mathrm{~K}_{2} \mathrm{HPO}_{4}, 0.02 \% \mathrm{MgSO}_{4} \cdot 7 \mathrm{H}_{2} \mathrm{O}, 0.02 \% \mathrm{KCl}, 0.2 \%$ $\mathrm{NaNO}_{3}, 0.02 \%$ yeast extract and $1.5 \%$ agar, adjusted to $\mathrm{pH} 6.0$ before sterilization) was inoculated into a 500-ml Erlenmeyer flask containing $100 \mathrm{ml}$ seed medium $\left(2.0 \%\right.$ glucose, $0.5 \%$ polypeptone, $0.05 \% \mathrm{MgSO}_{4} \cdot 7 \mathrm{H}_{2} \mathrm{O}$, $0.2 \%$ yeast extract, $0.1 \% \mathrm{KH}_{2} \mathrm{PO}_{4}, 0.10 \%$ agar, adjusted to $\mathrm{pH} 6.0$ before sterilization). The flask was incubated on a rotary shaker (210 r.p.m.) for 3 days at $27^{\circ} \mathrm{C}$ to obtain the seed culture. The production culture was initiated by transferring $2 \mathrm{ml}$ seed culture into each of the fifty 1 liter Roux flasks containing $200 \mathrm{ml}$ production medium $(3.0 \%$ sucrose, $3.0 \%$ soluble starch, 1.0\% malt extract, $0.3 \%$ Ebios (Asahi Food \& Healthcare, Tokyo, Japan), 0.5\% $\mathrm{KH}_{2} \mathrm{PO}_{4}$ and $0.05 \% \mathrm{MgSO}_{4} \cdot 7 \mathrm{H}_{2} \mathrm{O}$, adjusted to $\mathrm{pH} 6.0$ before sterilization) and fermentation was carried out under static conditions at $27^{\circ} \mathrm{C}$ for 14 days.

\section{Cell culture}

CHO-K1 cells (a generous gift from Dr Kentaro Hanada, National Institute of Infectious Disease, Tokyo, Japan) were maintained at $37^{\circ} \mathrm{C}$ in $5 \% \mathrm{CO}_{2}$ in
Ham's F-12 medium (Sigma-Aldrich, St Louis, MO, USA) supplemented with $10 \%$ heat-inactivated FBS using the method described previously. ${ }^{8}$

\section{Assay for TG and CE synthesis in intact $\mathrm{CHO}-\mathrm{K} 1$ cells}

Assays for TG, $\mathrm{CE}$ and phospholipid synthesis using $\mathrm{CHO}-\mathrm{K} 1$ cells were carried out using established methods with some modifications. ${ }^{9}$ CHO-K1 cells $\left(1.25 \times 10^{5}\right.$ cells per $\left.250 \mu \mathrm{l}\right)$ were cultured in a 48 -well plastic microplate. A sample $(2.5 \mu \mathrm{l}$ in methanol $)$ and $\left[{ }^{14} \mathrm{C}\right]$ oleic acid $(1 \mathrm{nmol}, 1.85 \mathrm{KBq}, 5.0 \mu \mathrm{l}$ in $10 \%$ ethanol/phosphate-buffered saline solution) were added to each well of the cell culture. The cells were cultured at $37^{\circ} \mathrm{C}$ in $5 \% \mathrm{CO}_{2}$. After $6 \mathrm{~h}$ incubation, cells in each well were washed twice with phosphate-buffered saline. The cells were lysed by adding $0.25 \mathrm{ml}$ of $10 \mathrm{~mm}$ Tris- $\mathrm{HCl}(\mathrm{pH} 7.5)$ containing $0.1 \%(\mathrm{w} / \mathrm{v})$ SDS, and the cellular lipids were extracted by the method of Bligh and Dyer. ${ }^{10}$ The total lipids were separated on a TLC plate (silica gel F254, 0.5-mm thick; Merck KGaA, Darmstadt, Germany) and the TLC plate was analysed with a bioimaging analyser (BAS 2000; Fujifilm, Tokyo, Japan) to measure the amount of $\left[{ }^{14} \mathrm{C}\right]$ lipids. Lipid synthesis activity (\%) was defined as $\left(\left[{ }^{14} \mathrm{C}\right]\right.$ lipid-drug $/\left[{ }^{14} \mathrm{C}\right]$ lipid-control $) \times 100$. The $\mathrm{IC}_{50}$ value was defined as the drug concentration causing 50\% inhibition of lipid synthesis.

\section{ACKNOWLEDGEMENTS}

We express our thanks to Dr K Nagai, School of Pharmacy, Kitasato University, for measurements of mass spectra.

1 Coleman, R. A. \& Lee, D. P. Enzymes of triacylglycerol synthesis and their regulation. Prog. Lipid Res. 43, 134-176 (2004).

2 Lewin, T. M. \& Coleman, R. A. Regulation of myocardial triacylglycerol synthesis and metabolism. Biochim. Biophys. Acta. 1634, 63-75 (2003).

3 Choi, S. H. \& Ginsberg, H. N. Increased very low density lipoprotein (VLDL) secretion, hepatic steatosis, and insulin resistance. Trends Endocrinol. Metab. 22, 353-363 (2011).

4 Mattson, F. H. \& Volpenhein, R. A. The digestion and absorption of triglycerides. J. Biol. Chem. 239, 2772-2777 (1964).

5 Ohte, S. et al. Dinapinones, novel inhibitors of triacylglycerol synthesis in mammalian cells, produced by Penicillium pinophilum FKI-3864. J. Antibiot. 64, 489-494 (2011).

6 Kawamoto, K. et al. Production of monapinones by fermentation of the dinapinoneproducing fungus Penicillium pinophilum FKI-3864 in a seawater-containing medium. J. Antibiot. 64, 503-508 (2011).

7 Uchida, R. et al. Structure and absolute stereochemistry of dinapinones A1 and A2, inhibitors of triacylglycerol synthesis, produced by Penicillium pinophilum FKI-3864. J. Antibiot. 65, 419-425 (2012).

8 Lada, A. T. et al. Identification of ACAT1- and ACAT2-specific inhibitors using a novel, cell-based fluorescence assay: indivisual ACAT uniqueness. J. Lipid Res. 45, 378-386 (2004).

9 Ohshiro, T., Rudel, L. L., Ōmura, S. \& Tomoda, H. Selectivity of microbial acyl-CoA: cholesterol acyltransferase inhibitors towered isozymes. J. Antibiot. 60, 43-51 (2007).

10 Bligh, E. G. \& Dyer, W. A rapid method of total lipid extraction and purification. Can. J. Biochem. Physiol. 37, 911-917 (1959). 